\title{
The Consumption of Tradition and Heritage Areas in the Grebeg Sudiro Event in Surakarta
}

\author{
Ogif Ratunar Rahmatulloh \\ Magister Architecture Department, Engineering Faculty, Universitas Sebelas Maret, Indonesia \\ Ofita Purwani \\ Magister Architecture Department, Engineering Faculty, Universitas Sebelas Maret, Indonesia \\ Paramita Rahayu \\ Urban and Regional Planning Program, Engineering Faculty, Universitas Sebelas Maret, Indonesia
}

\begin{abstract}
Cultural heritage cannot be separated from the traditions and identity of a society. However, heritage and tradition have become commodities for tourist consumption. They become interesting for tourists who look for 'authentic' experiences. Some of the so-called traditions commodified for tourism are intentionally made for a specific purpose. In this case it fits Hobsbawm's concept of 'invented tradition'. This paper focuses on the Grebeg Sudiro event, carried out by the Sudiroprajan community, in the city of Surakarta. This invented tradition has been held every Lunar New Year since 2008 in the Pasar Gede heritage area. The relationships between an invented tradition, tourism consumption, and place identity in a heritage area will be examined in this article. This article will highlight how heritage area as the venue for this event plays role in Grebeg Sudiro and how tourists can consume this tradition along with the heritage place as the venue. This research uses qualitative case study approach. Interviews conducted purposively and direct observations during the event were conducted to note and record the use of cultural heritage areas in the Grebeg Sudiro event, as well as to see how consumption of tradition takes place. Pasar Gede as a place of activity is considered as an interesting object and is considered to represent the identity of Sudiroprajan community. It can be said that invented traditions, cultural heritage identity, and tourism consumption are closely interrelated and complementary.
\end{abstract}

\section{Article History}

Received: 11 February 2020

Received in revised form: 09 June 2020

Accepted : 18 June 2020

Published Online : 31 August 2020

\section{Keywords:}

Invented tradition, consumption, heritage, Grebeg Sudiro

\section{Corresponding Author Contact: \\ ogifrahmatulloh@student.uns.ac.id}

DOI: $10.11113 /$ ijbes. v7.n3.548

\section{Introduction}

Grebeg is a tradition from Javanese culture. It is usually organised by Javanese royal courts in Surakarta and Yogyakarta whose dynasties still exist nowadays. In previous studies, Grebeg tradition was always considered something traditional but, in this case, we will discuss Grebeg as contemporary phenomenon in this modern world. This paper will also discuss Grebeg as invented tradition and will focus on the consumption of tradition and heritage place that take place in this event. This paper will discuss more about the contemporary tradition that uses heritage area and how that activity makes people consume the tradition, heritage area and everything shown at the venue. This study will be useful for people or agency (government, local community) to make tourism planning program that makes use of existing heritage site(s) to attract tourists. New traditions can be invented from existing cultural values to make what 
Hobsbawm calls 'invented tradition'. Invented tradition always adopts the format of real or long-established tradition in order to make the new form of tradition appear as authentic. Invented traditions spread massively in Indonesia, especially in Surakarta after the 1999 Decentralization. One of those invented traditions is Grebeg Sudiro of Surakarta. This Grebeg is so successful as tourist attraction and has been popularly accepted as 'tradition' that it is held annually by the municipal government of Surakarta.

Originally, Grebeg is a ritual carried out by the royal court of Surakarta as a manifestation of the king's alms to his people. The implementation of Grebeg involved the royal family, royal apparatus, and all the people. The Grebeg has an attribute called Gunungan (figure 1), which is a mound of agricultural harvest and traditional snacks. This Gunungan is paraded around the Keraton (the royal palace) then stopped at The Great Mosque of Surakarta for some rituals before being distributed to the people. This ceremony is a symbol of the king's generosity as a legitimate regal effort (Purwani, 2014). Meanwhile, Grebeg Sudiro is an invented tradition of the royal court's Grebeg which shows a cultural integration between the Javanese and Chinese traditions. We use Grebeg Sudiro as case study for this research because this event is the first contemporary Grebeg in Surakarta and Indonesia. This event, which emerged in 2008, was initiated by the local community of Sudiroprajan urban kampong and is held in the cultural preservation area of Pasar Gede, a historical market place which dates back to $18^{\text {th }}$ century. The aim of Grebeg Sudiro is to communicate and to promote the theme of cultural diversity (Widyaningsih \& Purwasito, 2018). The Pasar Gede area has an important role as a source of identity and inspiration for Grebeg Sudiro. The area has long been a multicultural area inhabited by Chinese and Javanese people. This event highlights the identity of the region and represents harmony among ethnicities.

Pasar Gede has long been known as a historical traditional market in a multicultural setting. Grebeg Sudiro, then, can build its narrative through this historical place to make people believe that Grebeg Sudiro is an 'authentic' tradition despite the fact that it is a recent invention. Cultural heritage objects such as Pasar Gede are produced and consumed when an event takes places in it. The level of cultural consumption relates to and is informed by the demand profiles of heritage sites and services. During the event, several groups of local people sell souvenirs and snacks for tourists. At a different level the participants of Gebeg Sudiro become an attraction for tourists who want 'to consume' the tradition, the values it represents, as well as the snacks. Grebeg Sudiro consists of three activities, namely: a) Umbul Mantram, which is a procession held by local people internally, b) Pepe river boat tours: a local boat tour along Pepe River, a river located very close to Pasar Gede c) the Grebeg Sudiro cultural carnival as the highlight of the event. This annual event is massive, attracting many tourists not only from the city of Surakarta but also from other parts of Indonesia.

Consumption of traditions is unavoidable because of the globalisation era (Ashworth, 2010). Heritage, as part of a culture, is consumed by people who search for 'authenticity', even when some parts of it might be invented. Consumption of tradition is a manifestation of cultural demand. The production of cultural heritage sites ranks those sites as economic income land, and so many countries now actively apply for heritage recognition in order to earn income from tourists' visits (AlSayyad, 2001). This consumption relates to and defines how tourists who visit consume a destination, with that area in the city becoming a leisure product. Such a heritage element can be categorized as an activity place and leisure setting in the host city (Khairi et al., 2019). The commodification of cultural and heritage areas is closely related to consumption and tourism.

A heritage area is part of the development of cultural aspects in a region or country. Such an area is not only a memorial but also a source of value for a community. Cultural heritage objects as a source of identity can be packaged and transformed into new traditions to meet or satisfy certain interests. Cultural modification has become trends in Indonesia (Musthofa, 2017), as well as in other parts of Southeast Asia. One example of this is Malacca in Malaysia. Malaysia is a popular destination, with tourism becoming increasingly popular and significant (Ismail et al., 2014). Malacca is a port city that participated in over 600 years of trading in the Straits of Malacca. The ships and crews from other nations have caused Malacca to have a cultural mix of Malay, Chinese, Indian, English and Portuguese; a mix that influenced the architecture of the historical building that survive in Malacca (Fazil et al, 2014). In the same way, Sudiroprajan is a heritage area in Surakarta where people of Javanese and Chinese ethnic live together for decades. Their cultures mix and influence the building and the cuisine in Sudiroprajan. The types of heritage in Sudiroprajan and Malacca have cultural

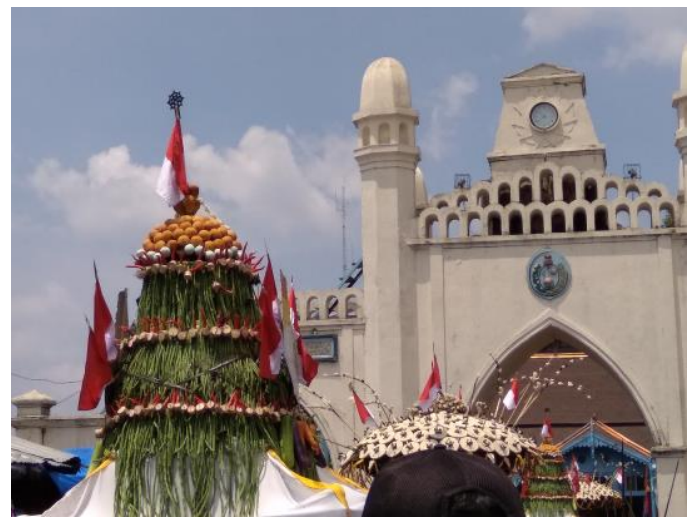

Figure 1 Gunungan 
diversity and heritage sites for tourism consumption.

This study has significance in building knowledge on invented tradition and the consumption related to that that includes heritage place as the venue of the invented tradition. We draw basic conclusions about the forms of production and consumption in the heritage areas, so that the findings can contribute to the efficient development of heritage festivals, especially in Surakarta. The results can be correlated with decisions to visit a heritage destination. They can also be correlated with the levels of perceived authenticity at the time when the event is held. Such data will be of interest and value to heritage managers, as well as the local people who want to create their own heritage festivals.

\section{Theoretical Review}

\subsection{Invented Tradition and Places Identity}

Tradition is shaped by the conditions and potentials of individuals in the interaction between the environment and socio-cultural variables (Soemardi, 1974). Invented tradition is a ritual activity that tries to embed certain values and norms in society through repetitive association with appropriate history (Hobsbawm, 2012). These associations can be made by using narratives. Cultural heritage can be used to build narratives for invented tradition as it has historical value to associate with. The value of cultural heritage is not only about the history of them but also about memories and values embodied in them. Those values are passed on from generation to generation. This heritage can appear in varied types such as: a) built environment, b) traditions, c) languages and d) places commemorating historical events. Some of them are tangible, such as building areas, while some others are intangible such as: a) dance, b) cultural norms and values, c) lifestyle dress and d) handicraft (Ismail et al., 2014). In addition, the heritage's existence reflects social system and activities that take the forms of intangible and tangible objects (Ginting \& Rahman, 2016). Cultural heritage object is therefore important, as its existence reflects the patterns and social activities of a society and is therefore an interpretation of the inherited objects, tangible and intangible (Ginting \& Wahid, 2015). Cultural heritage does not have fixed meaning. Its meaning is attached by its society to a heritage building or area. That meaning does not need to be permanent. It can change according to continuing economic and socio-political events, in association with collective memory, tradition and sense of belonging (Musthofa, 2017).

Another causative factor of invented tradition is bottom-up initiatives from community, which Sztompka calls "creative minorities". The concept of creative minorities is at the root of this phenomenon where local groups are motivated to achieve something (Sztompka, 2011). Tradition arises because the initiative stem from the community: a) can be widely accepted and adopted by the society, b) happen continuously rather than just once and c) is formalized. One form of the invented tradition is an event or activity that commemorates a certain date. Events are social phenomena found in human culture and realized through various activities such as: i) choreography, ii) dramatics and iii) dynamic aesthetics that are interpreted from the deep meanings that underlie a noteworthy event's historical roots (Fallasi, 1987). The heritage's existence is relevant to the historical value of community around. The local groups who live around or near to heritage environments try to preserve the object because the existence of heritage can help community and village to sustain (Aziz, 2017). On the other hand, local people create their 'new tradition' festival as a way to enable their community to sustain and to preserve the valuable heritage that exists in the community.

Invented tradition is the result of the metonymy of values in the history of a place. A place that has a certain history is a source of identity construction, not only of the specificity of the place but also the construction of meaning from the place (Grey \& O'Toole, 2018). Place identity is then a significant factor in invented tradition because place can build the narratives background. The stronger the place identity, the easier for the narratives to be formalized by its wider community. A place can reflect the structure of identity; an entity that consists of a) the physical environment, b) memories, c) feelings, d) values and e) conceptions of human behaviour in the area. Identity can shape a place and gives meaning to the place through a) social interaction, b) symbolism and c) the history behind that place. Identity and place, then, have a very close relationship (Sukri \& Radzuan, 2018). The relationships between people and places cause an area to be invested with symbolic meaning in the context of the community and to identify and engender emotions related to the scope of the local community (Lalli, 1992). Identity ownership is intrinsically related to the relationships with: i) the natural and social environment, ii) cultural heritage or iii) historical place for a personal collective view of the present and the future (Edwards, 1998). Moreover, heritage area as places have relationship with identity of people who live around the places. Historical places become source of identity and value of community and this important for commodification itself.

Here we examine the factors that influence place identity, such as: a) distinctiveness, b) continuity, c) self-esteem, d) selfefficacy (Breakwell, 1986). The four principles can be described as follows:

- Distinctiveness: the desire to maintain otherness or to be different from the characteristics of 'the other'.

- Continuity: continuity of one's self-concept.

- Self-esteem: evaluation of self-identification, formed from the perception of pride in a place.

- Self-efficacy: belief in one's ability to work successfully in a particular social environment.

The place's identity is maintained to reinforce and to strengthen feelings, a situation that can lead to the perception of authenticity. In this case, place identity is used in invented tradition because it delivers values to suggest authenticity. 


\subsection{Cultural Heritage and Tourist Consumption}

Heritage is a subject of great interest in today's world. Cultural heritage tourism is increasingly on demand. This motivates the surrounding community to explore the potential of existing heritage sites and sources. Heritage, as a focus of tourism, may serve as powerful tools to promote the identity of community to wider society (Butler, Khoo-Lattimorea \& Mura , 2014). A desired or looked-for cultural experience is one of the factors that make tourists come to a place, where something new is on offer (Urry, 2002). The 'tourist experience' is what drives cultural heritage promotion; not only the heritage area but also the issues of culture, leisure and social interactions which can cause visitors memorize and value their heritage related experiences (Teoa, Khanb \& Rahima, 2014). As the demand for authentic cultural experiences increases, a well-framed cultural event will cause many tourists to visit. This can increase income opportunities for those who offer services to visitors (AlSayyad, 2001). The aim for this heritage tourism is to deliver quality experiences to tourists; with the primary element includes attractive, culturally authentic products that are available in urban heritage settings (Khairi, et al., 2019)

Cultural identity through its commodification represents cultural consumption (Valentina et al., 2015). This situation can be directly attributed to the invented tradition, called a 'remake' of a tradition carried out for a particular purpose. With invented traditions spreading across heritage areas, it is possible to make many of those areas highly popular and attractive to visitors. It is not only the heritage sites with their cultural connections that attract tourists; another factor that is important for tourism relates to the quality of the site's infrastructure and tourist services available (Teoa et al., 2014). This issue pushes the host to produce quality services and complementary activities to gain more consumption and therefore profit. The initial program offered by the host community can improve a visitor's cultural experience; whilst good facilities can most certainly increase visitation rates
(Alberini \& Longo, 2006).

Tourism is an industry that has the potential to be of great benefit to a country's economic sector; contributing to local communities by creating opportunities to develop their potential (Puah et al., 2018). Cultural heritage tourism will be increasingly linked to cultural production because performances have a high attraction value for tourists. Culture is packaged in a show with narrative stories and imagery made by the community with the producers, so that the culture can be more attractive as a consumer item (Pelly, 2015). The narrative that is formed is the result of people's interpretations of the physical culture and environment, including cultural heritage objects. However, the consequences of cultural commodification are forms of rituals that are often shortened and simplified so they appear magical: religions will be modified because the purpose is limited to entertaining the audience and experiencing secularization, even though this does not occur in all cases (Dharma, 2018). Cultural tourism is something beneficial to the providers as a result of current economic trends. Consumption of cultural tourism develops and creates markets where tourists are willing to spend money to look for various cultural products, the more authentic the better (Ashworth, 2010).

Figure 2 shows that heritage as a place can reflect the value of social and cultural values of a community. Those values can be used as narratives for invented traditions. The invented traditions will then affect the social identity of community by embedding the values in the invented tradition. At the same time, invented traditions are also related to economy in that the trend of cultural heritage tourism makes opportunities for invented tradition to develop. Invented traditions, then, can contribute more to the cultural heritage tourism by providing authentic experience to tourists.

\section{Methodology}

This study applies qualitative case study approach. As argued by

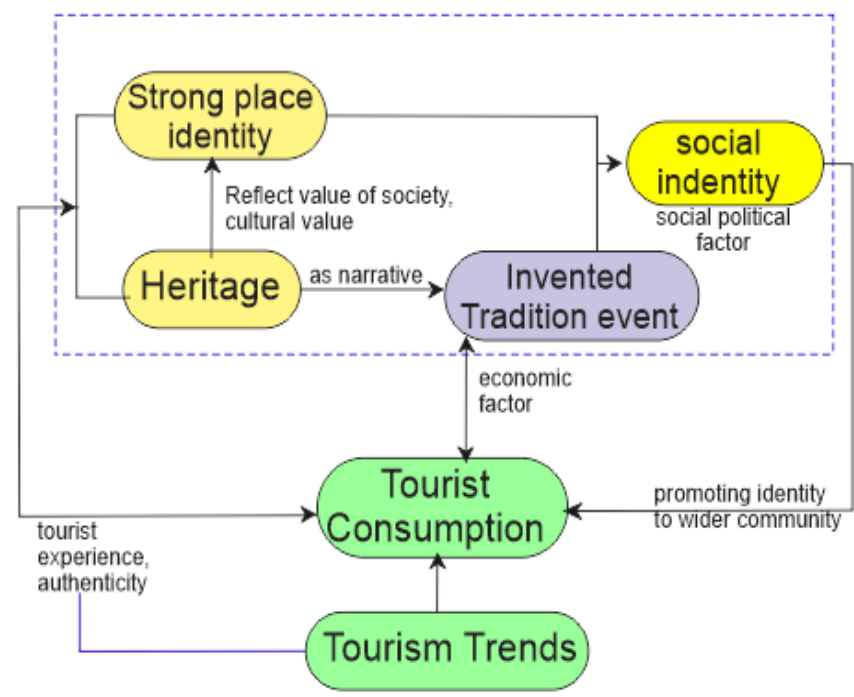

Figure 2 The Dynamic between Heritage, Invented Tradition and Tourist Consumption 
Flyvbjerg, (2006), case study is not intended to make a generalization, but it is to be used as "a force of example" on the importance of the substance under investigation by using a very particular case. This research will investigate the consumption of traditions in the cultural heritage site along with the on-going activities in the area by using qualitative case study approach. Sudiroprajan is selected as the case study because that urban kampong has a heritage area, with Pasar Gede and Klenteng Tien Kok Sie as the icons. Its community is unique, multiethnic, with tradition held every lunar year to celebrate their tolerance and unity in diversity called Grebeg Sudiro.

This research is conducted at Pasar Gede Heritage Area where the Grebeg Sudiro event is held. In order to examine the consumption of tradition in heritage area in Grebeg Sudiro event, this research organizes the following steps: a) explore the background of the Grebeg Sudiro as invented tradition activities and its relationship with place identity, b) identify the forms of consumption when the event take places c) identify the importance of heritage area as an event venue, with interviews.
Before doing the interviews and field observation, a guideline is arranged by the following themes:

- History of heritage area that influence Grebeg Sudiro

- Values hold by community that influence Grebeg Sudiro

- The identity of the heritage area and the community

- The reason for Grebeg Sudiro to be held and what is invented from original tradition of Grebeg

- Expected outcome by the host

- Activities that show the production and consumption in heritage site when Grebeg Sudiro held (area in heritage site that is consumed by tourist)

- Spatial layout of the site and and facilities provided when Grebeg Sudiro is held

- Activities by local community

Respondents for interviews are categorized as follows (table 1):

Table 1 Respondent and Information

\begin{tabular}{|c|c|c|}
\hline No & Position & Information \\
\hline 1 & $\begin{array}{l}\text { Official department of } \\
\text { tourism }\end{array}$ & $\begin{array}{l}\text { - The effect of tourism in Surakarta when Grebeg Sudiro held } \\
\text { - Importance of Grebeg Sudiro }\end{array}$ \\
\hline 2 & $\begin{array}{l}\text { Department of Sudiroprajan } \\
\text { urban kampong }\end{array}$ & $\begin{array}{l}\text { - Legality of Grebeg Sudiro tradition } \\
\text { - Explanation about committee formation and preparation } \\
\text { - Facility fulfillment in Grebeg Sudiro } \\
\text { - Importance of program Grebeg Sudiro } \\
\text { - Grebeg Sudiro's background, why use Pasar Gede as venue } \\
\text { - Route of Grebeg Sudiro } \\
\text { - District and social identity }\end{array}$ \\
\hline 3 & Tien Kok Sie Commite & $\begin{array}{l}\text { - Ritual that happen in Grebeg Sudiro } \\
\text { - History of Grebeg Sudiro } \\
\text { - Role of Klenteng }\end{array}$ \\
\hline 4 & Pasar Gede Commite & $\begin{array}{l}\text { - Role of member of Pasar Gede } \\
\text { - Increase of visitation in Pasar Gede when Grebeg Sudiro held }\end{array}$ \\
\hline 5 & Grebeg Sudiro Founder & $\begin{array}{l}\text { - History of Grebeg Sudiro } \\
\text { - Background and purpose of Grebeg Sudiro } \\
\text { - Importance of Heritage area Pasar Gede and Klenteng in Grebeg } \\
\text { - Sudiro } \\
\text { - Route of Grebeg Sudiro and local people activity } \\
\text { - Social identity of Sudiroprajan }\end{array}$ \\
\hline
\end{tabular}




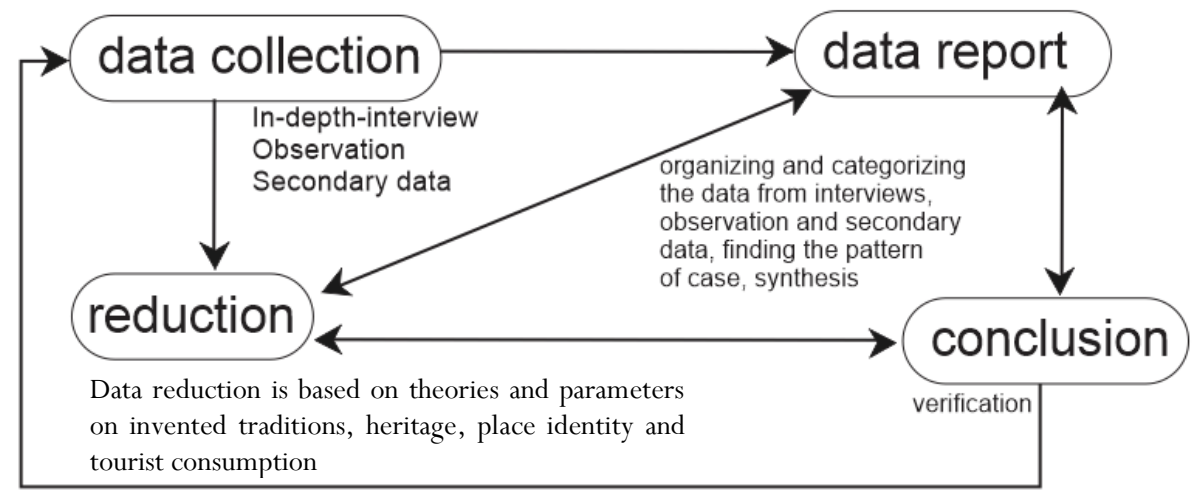

Figure 3 The process of analysis

Source: Modified from Miles and Huberman (1992)

The process of analysis is shown in Figure 3. After collecting data from in-depth interviews, observation, and secondary sources, we organize and categorize the data to find any patterns that might exist. It also includes the process of reduction, which is based on the theoretical framework, before going into conclusion. Qualitative research is based on categorization, concepts, and description on the development in field activities. Data collection and analysis are impossible to separate. Both processes happen simultaneously (Miles and Huberman, 1992).

Eight persons were interviewed in this research. In addition to that, we observe the activities in situ which includes the activities of the event, also the activities of the tourists. The observation also looks for the attribute and location, and the route of the event to find out the role of heritage area in the procession of Grebeg Sudiro. The secondary data is collected from documentation and report from the neighborhood office of Sudiroprajan. The documentation consists of the activities of local people and organizing committee, before and after the procession of Grebeg Sudiro. Other source of secondary data is previous research about Grebeg Sudiro and Pasar Gede heritage area. After data collection, the data is reduced by using the theoretical framework and decided parameter before being categorized to find any patterns that lead into conclusion.

\section{Result and Findings}

Sudiroprajan is an urban kampong with multi-ethnic population including Javanese and Chinese people (Rusdiyana, 2018). Sudiroprajan has Pasar Gede as the main market (figure 4), which has been carrying out its activities for almost three centuries. Its history began in 1745 in the era of Pakubuono II, at which time Chinese citizens were forbidden to live inside the Keraton of Surakarta. The official name of this market is Pasar Gede Hardjonegoro, the name being taken from a Chinese descendant who was given a royal title KRT Hardjonegoro by the royal court of Surakarta. Not far from the market, there is the Tien Kok Sie temple, which is a place of worship for Chinese people, and which has been acknowledged now as a heritage building. Near Pasar Gede, there is a 'Chinatown' known as Balong village, which now is not only occupied by residents of Chinese ethnicity but also by people from other ethnic groups. There is a good social interaction between the Chinese and Javanese communities in the area and its surrounding. Mixedethnic marriages are also common in those communities.

Through direct observation we find that Pasar Gede is a vital area for the Sudiroprjan people, so they make an event cantered on Pasar Gede, namely 'Grebeg Sudiro'. At first, this event appeared to enliven the anniversary of Pasar Gede, but gradually the program grew bigger and involved more and more people. Today it has grown not only of one single event, but a series of events in one period around the Chinese Lunar New Year. Pasar Gede occupies an important position in the creation of Grebeg Sudiro activities. Grebeg Sudiro as an invented tradition modifies Grebeg which is originally a ritual event of the royal court of Surakarta. Grebeg Sudiro has adopted components from the original tradition. New formations of traditions, with appropriate narrative, will be accepted by the community and formalized, according to Hobsbawm. Creating repetitive

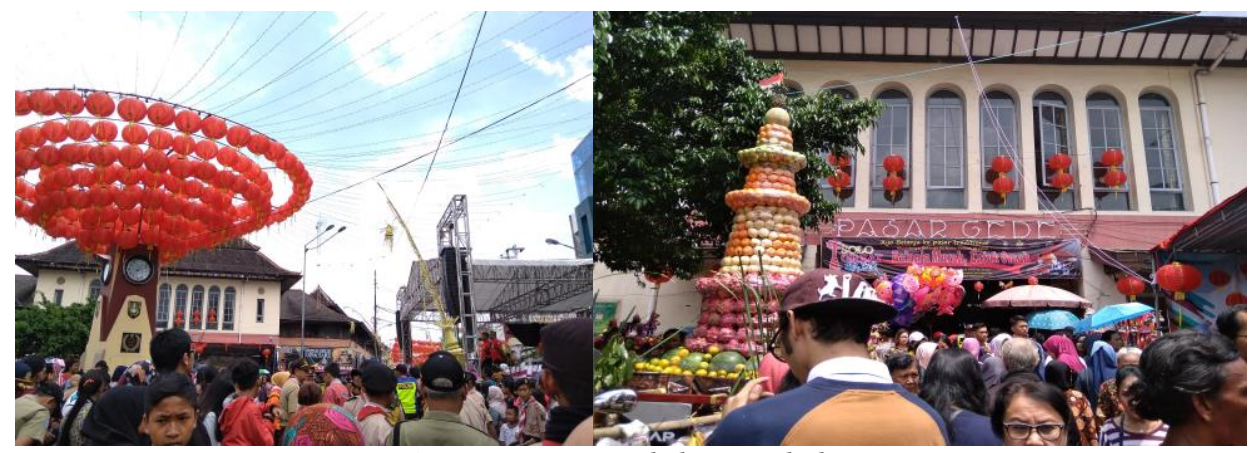

Figure 4. Pasar Gede historical place 


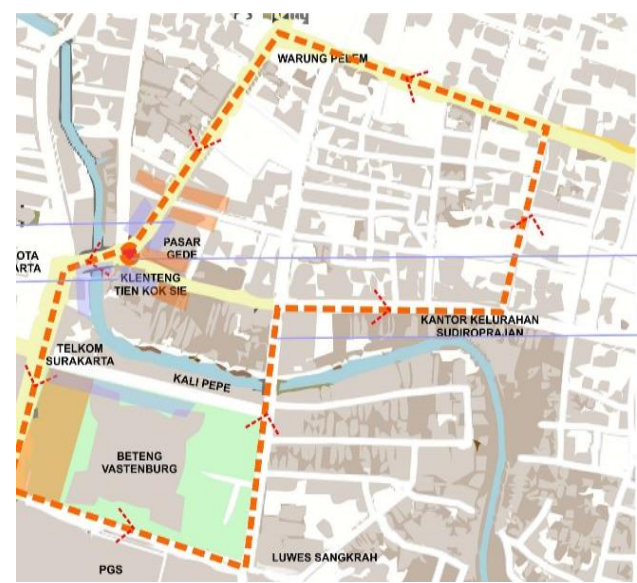

Figure 5 Grebeg Sudiro Route

activities and representing certain values that have a correlation with the past are practices of the invented tradition.

"The aim of Grebeg Sudiro is for tourism. Local people hoped this event can attract many tourists and bring economic benefit to the locals. In addition, this event indicates the existence of the cultural attraction possessed by Sudiroprajan community who want to show that this neighbourhood has a history of acculturation between Chinese and Javanese communities and cultures"

(Interview, 2018).

Although each ethnic group has their own cultural characteristics, they have blended together to create a unique regional identity (Ismail, et al., 2014)

And Malacca literally has the same role too; with its uniqueness of the cultural mixture of the people living in there that has built up over several centuries. Because of its ethnic diversity generated by Chinese, Malaysians, Portuguese, Dutch, English and Indians, various heritage sites make up the identity of that region. The acculturation between different ethnic groups grown naturally over hundreds of years and that process has built today's Malay national identity (Worden, 2003). In Malacca there are three traditional villages that are conserved in Malacca state: Kampung Morten riverine village, Kampung Chetti (Kampung of Peranakan Indians) and Kampung Portuguese. Those three groups believe that living heritage sites can help their communities sustain and advance their cultural pride and identity by creating cultural awareness of and by their own unique cultural aspects (Aziz, 2017). From the descriptions above we can expect that areas involved with or demonstrating cultural heritage and history are sources of identity for the Sudiroprajan community and the Malaysia/Malacca people too. Grebeg Sudiro is communicated through four symbols, namely Gunungan, Jodang, art parades, and the annual thematic Grebeg Sudiro event which reflects the spirit of cultural diversity. Gunungan is one form of invention to resemble the element from the original Grebeg event.

"The theme of Grebeg Sudiro is the result of the values found in the history of the Sudiroprajan urban kampong, which is based on the Chinese and Javanese communities. The theme cannot be separated from the cultural heritage area of Pasar Gede as a symbol and as a source of identity. The event, then, structures the identity and experience of the local community." (interview 2018)

Even before the inception of Grebeg Sudiro, Pasar Gede was already known as an icon of the Surakarta. Therefore, Grebeg Sudiro deliberately uses the Pasar Gede as a venue to make their event known well as part of local cultural heritage, so that the event can be elevated and become popular. The latter is an example of one of the production processes associated with Grebeg Sudiro. Pasar Gede is important for the local people to make an invented tradition event. The Sudiroprajan community deliberately makes the narrative of the event related to history, including its relationship to objects of cultural heritage. The market, which has a strong place identity, has taken its historical value and developed into the theme of the invented tradition of

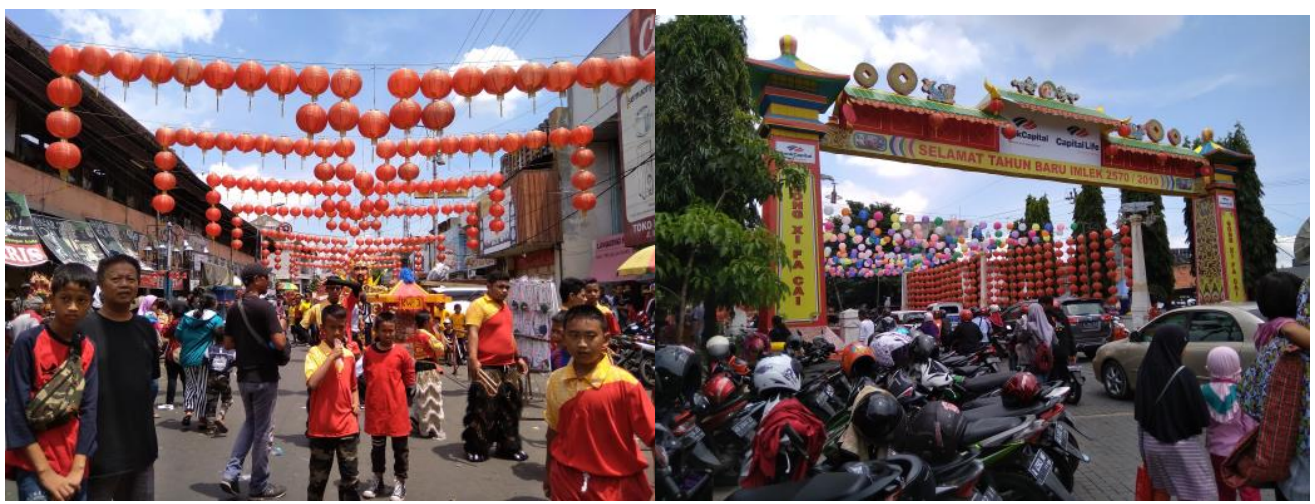

Figure 6 Gate and Lampion Decoration Near Tugu Pemandengan 
the Sudiroprajan community, which indirectly labelled itself as a community that has the tradition.

With a strong identity, unique places, and traditions that are displayed, the event will attract many visitors. The combination among them is a cultural production ready for consumption by tourists. The identity of the Pasar Gede as a place can also be accessed through the four principles of identity, namely: a) distinctiveness, b) continuity, c) self-esteem, and iv) selfefficacy. Distinctiveness is related to positive perceptions of the uniqueness of a place. In this event, Pasar Gede, Tien Kok Sie temple, Tugu Jam, Pemandengan, and Kali Pepe contribute as an interesting element because of their unique, historical difference from other places. Pasar Gede building is a landmark of the region that gives its impression both for the people who live around there and for visitors. Cultural attraction also becomes a positive value for people to remember a place, as shown in the Grebeg Sudiro event as a complementary element of an area with a strong identity. Self-esteem is defined as a positive self-evaluation or group by which a person identifies and produces pride.

The Pasar Gede area as a historic area and place is a source of pride for the surrounding community. It is said that Pasar Gede produces a particular identity among local people and that identity is expected to be accepted by wider society. The local community tries to show its identity more through events such as Grebeg Sudiro. There could be a problem when Pasar Gede, which is an iconic place, loses its identity, as it will eventually be abandoned; therefore, the sense of such iconic places must be conserved. This also happens in Malacca heritage area, in that the existence of heritage sites cannot be separated from the local community, that consists of several ethnic groups (as cited before). It can be said that local communities play the roles of actors doing things that affect heritage preservation through various activities. Self-efficacy is also important. This includes the provision of elements to make tourists more comfortable such as a) accessibility, b) markers, and c) public facilities. The availability of these facilities can increase the satisfaction of both locals and visitors. Tourists or visitor may expect appropriate standards of comfort facilities; therefore, the site must be set up to provide those facilities.

Grebeg Sudiro uses the heritage place and produces a show framed by cultural themes. Tourism production is carried out by citizens' initiatives, which creatively provide interesting background narratives in the Grebeg Sudiro event. Grebeg Sudiro is initiated by the district government, local community, Pasar Gede foundation, and Tien Kok Sie temple association. Furthermore, because the event is considered to have economic value, the Sudiroparjan urban kampong as stakeholders legalize and make it a potential tourism event. The Grebeg preparation area is not in Pasar Gede but the Sudiroprajan urban kampong office. In this case, the market plays a role as a stage and the village office as a backstage. The route of the Grebeg Sudiro event is also of some interest because it shows the heritage landscape in the Pasar Gede area.

"The participants of Grebeg move from the market stage to the main street and go around to Balong Chinese village and then come back to Pasar Gede again. This carnival route (figure 5) has a purpose to show the people following the event about their territory and peculiarity of their region; as well as aiming to introduce their places as part of a cultural community." (interview, 2018)

The Pasar Gede area is transformed into a stage of cultural attraction. Lanterns and other Chinese ornaments decorate the market area starting from the front side of the Klenteng area (figure 6). The bridge is decorated, and there is also a gate placed on the side of the bridge. Moreover, the front area of the road leading to the fort is also decorated with zodiac-shaped lanterns. Another phenomenon that arises is the number of street vendors on the side of the Pasar Gede area, especially in the side of the bridge. All these activities are tourism productions. The community is ready to meet the needs of visitors ranging from snacks and souvenirs to parking service for visitors' vehicles. All of these interest public to come. They are also willing to spend their money for experiencing the events. In the same way in Malacca, the tourists consume according to the primary attractions in the heritage areas and consume the services provided, as well as spending their money on food beverages and souvenirs (Khairi et al., 2019). In Malacca tourists are interested to participate in cultural attraction. So, the governor of Malacca provides what the tourists want and made some festival for the tourists to participate. The ease of access to information also adds to the consumption of traditions in that area. The impact of publication in the mass media also 'blows up' the event and can encourage many tourists to consume the facilities and services provided by local people when the Grebeg Sudiro event takes place. Tourism consumption is massive in the area, especially when the peak event takes place, as the producers make the stage go right across the Pasar Gede.

\section{Discussion}

Grebeg Sudiro as a contemporary event and we can call it invented tradition. For an invented tradition to be recognized as traditional, it is important for it to use narratives. Historical value is very important to drive society to accept the invented tradition. Invented tradition consisting ritual practice with certain value in society trough repetition of ritual by linking with appropriate history (Hobsbawm, 1992). Grebeg Sudiro uses the history of Sudiroprajan urban kampong that has a long history on the peaceful interaction of Javanese and Chinese communities- as narratives to support the event to be considered 'traditional'. Grebeg Sudiro as an invented have specific purpose to make branding or to show local community identity -as an old and unique community that exist till nowand to highlight their cultural art through history. The community movement in Sudiroprajan is an important aspect to make Grebeg Sudiro have its own characteristic. The community known well the potency of Pasar Gede Heritage area and the uniqueness of acculturation there. Their movement also an activity to make the Heritage around Pasar Gede been preserved and popular in wider community. In Mellaca Heritage site local community also involve efforts to conserve their 
heritage by cultural attraction and festival they had. Local people are having some purpose and do creative movement to achieve that (Sztompka, 2011). Local people live around heritage try to preserved the value of the heritage object (Aziz, 2017). Another aspect that contributes to the recognition of Grebeg Sudiro as a 'tradition' is institutional acknowledgment by the municipal government.

Pasar Gede plays an important role in this event. This heritage building is popular landmark in Surakarta city and it becomes the icon of Grebeg Sudiro. Heritage reflect tangible aspect like cultural norms and values in society (Ismail, Marson \& Ahmad, 2014). Pasar Gede reflect ethinic diversity, that value used by Grebeg Sudiro as event theme. Pasar Gede area has built a strong identity in urban scope. In other side Melaka with multi ethinc acculturation among hundred years build identity from their ethnic traditional village in heritage site. Those diversities are pride and become Malay national identity. Identity ownership is relating with historical and cultural heritage (Edwards, 1998), relationshop between peoples and places cause an area invensted some symbolic meaning realed identity of local community (Lalli, 1992). From that we can conclude that identity, heritage and community have dynamic relation. Community can get identity from historical heritage and heritage places can get stronger identity from ethnic community.

Grebeg Sudiro takes an advantage from the situation to make the event noticed by people. Without Pasar Gede as its venue, Grebeg Sudiro might not be as successful and as popular today. Everything shown in Grebeg Sudiro is complex, and the event produces an attraction and (heritage) places to consume. Heritage area can be tourism object that promote community identity (Butleret al., 2014), beside that heritage as tourism has potential benefit to ecomomic sector (Puah et al., 2018).

Grebeg Sudiro involves not only cultural attraction, but also heritage place and legitimizing narratives. The interconnectedness of the three aspects makes Grebeg Sudiro a 'tradition', therefore it is considered to have traditional and cultural value. This makes it interesting for tourists who search for cultural experience as they always look for authentic symbolic experience as alternatives. Heritage tourism offer experience with cultural authentic products (Khairi, et al., 2019). Culture attracton and narrative history that produce can be goods for consumer (Pelly, 2015). The cultural program offered by local community can improve visitor experience and with additional facilities the visitor will increase (Alberini \& Longo, 2006). The local community provide what visitor needs, they open parking area, snack and souvenir street vendor. And this happen in both Grebeg Sudiro and Melacca. The tourism authority plays an important role in the development of responsible tourism attraction, so that stakeholders focus on heritage and culture to create the consumption of tourism_(Teoa et al., 2014). At the present-day Grebeg Sudiro, tourists come to the venue not only at the exact time when the ritual was conducted but also days before or after the event, only to consume the decorated spaces and the food sold in the Pasar Gede area.

\section{Conclusion}

The Grebeg Sudiro event is a cultural production that reflects the identity of the Sudiroprajan community. That value is lifted from the heritage and community uniqueness. The Pasar Gede area, as a cultural preserve located in Sudiroparjan urban kampong, is the place where the event takes place because it is considered to promote the event's message. Cultural production is carried out by the community and institutionalized to elevate Sudiroprajan's cultural identity. Pasar Gede, as the main performance venue, was chosen because it is an iconic historical place and has a strong identity of its own as well as with the community. This identity strengthening through the specificity of a region encourages and attracts tourists to come and feel the atmosphere that is different from other places. Heritage plays important role to the attraction and this not only happen in Grebeg Sudiro but also in Melaka Heritage site. Tourism is the reason for the creation of traditions, because such initiatives are profitable; tourists provide income by bringing spending power to an area or event. Cultural heritage that is unique will certainly attract attention and be used to meet and satisfy tourism consumption. Consumption of traditions and cultural heritage has a close relationship. Heritage offers a unique experience with a strong identity, it is easy to make a demonstration of the values and symbols, but it also depends on the initiator and stakeholders as the main actors in tourism production.

This research can still be developed with a variety of other cases, with different approaches and methods. The study of tourism and its relationship to cultural heritage is something that is currently being discussed because, at present, the growth of massive tourism. It is expected that further research will be more detailed in nature, in order to examine cultural heritage from other perspectives.

\section{References}

Alberini, A., \& Longo, A. (2006). Combining the travel cost and contingent behavior methods to value cultural heritage sites: Evidence from Armenia. Journal of Cultural Economic, 30(4): 297-304.

AlSayyad, N. (2001). Consuming Tradition Manufacturing Heritage. New York: Routledge.

Ashworth, G. (2010). How Do Tourist Consume Heritage Places? Examining the Assumption. Tourism Recreation Research, 281-290.

Aziz, R. A. (2017). Heritage Conservation: Authenticity and Vulnerability of Living Heritage Sites in Malacca State. Kajian Malaysia, 39-58.

Breakwell, G. M. (1986). Coping with Threatened Identities. London: Methuen.

Butler, G., Khoo-Lattimorea, C., \& Mura, P. (2014). Heritage Tourism in Malaysia: Fostering a Collective. Asia Pacific Journal of Tourism Research, 19(2): 199-218.

Dharma, F. A. (2018). Komodifikasi Floklor dan Konsumsi Pariwisata di Indonesia. BioKultur, VII: 1-15. 
Edwards, J. J. (1998). The need for a 'bit of history': place and past in English identity. In N. Lovell, Locality and Belonging. 88-147. United Kingdom: Routledge.

Fallasi, A. (1987). (ed) Time Out of Time. Mexico: University of New Mexico Press.

Fazil, F., Razak, M. I., Marshahadi, F., Yusof, A. M., Sakrani, S. N., \& Wahab, S. A. (2014). Measuring Tourist Propensity to Visit Heritage City of Malacca, Malaysia. Internatioanl Journal of Economics, Commerce and Management, 2(12): 1-12.

Flyvbjerg, Bent. (2006) "Five misunderstandings about case-study research." Qualitative inquiry 12(2): 219-245.

Ginting, N., \& Rahman, V. (2016). Preserve Urban Heritage District based on Place Identity. Asian Jurnal of Environment-Behaviour Studies, 1(1):67-77.

Ginting, N., \& Wahid, J. (2015). Exploring Identity's Aspect of Continuity of Urban Heritage Tourism. Procedia - Socila Behavioral Science, 202:234 - 241 .

Grey, C., \& O'Toole, M. (2018). The Placing of Identity and the Identification of Place: "Place-Identity" in Community Lifeboating. Journal of Management Inquiry , 29(2): 206-219.

Hobsbawm, E. (2012). The Invention of Tradition. United Kingdom: Cambridge University Press.

Ismail, N., Masron, T., \& Ahmad, A. (2014). Cultural Heritage Tourism in Malaysia: Issues and Challenges. SHS Web of Conferences, 1 8.

Md Khairi, N. D., Ismail, H. N., \& Jaafar, S. M. (2019). Tourist behaviour through consumption in Malacca World Heritage Site. Current Issues in Tourism, 22:5, 582 600, DOI: $10.1080 / 13683500.2018 .1491534$

Lalli, M. (1992). Urban-related identity: Theory, measurement, and empirical findings. Journal of Environmental Psychology 12(4) : 285 - 303.

Miles, M.B \& A.M, Huberman, 1992. Analisa Data Kualitatif: (Translated by: Tjetjep Rohendi R). Jakarta: Universitas Indonesia Press.
Musthofa, B. M. (2017). Saung Angklung Udjo:Invensi Tradisi Lokal yang Mendunia. Antropologi Indonesia 2: 137.

Pelly, U. (2015). Entitas dalam Politik Multikultural (buku 1). Medan: Casa Mesra.

Puah, C.-H., Jong, M.-C., Ayob, N., \& Ismail, S. (2018). The Impact of Tourism on the Local Economy in Malaysia. International Journal of Business and Management, 13(12):148-153.

Purwani, O. (2014). Javanese Power: Silent Ideology and Built Environment of Yogyakarta and Surakarta. Edinburgh: Doctoral Thesis. The University of Edinburgh.

Rusdiyana, N. (2018, Mei 10). Retrieved Oktober 20, 2018, from http: / / surakarta.go.id/?p=9957

Soemardi, S. S. (1974). Setangkai Bunga Sosiologi. Jakarta: Lembaga Penerbitan Fakultas Ekonomi Universitas Indonesia.

Sukri, S., \& Radzuan, A. W. (2018). The Making of Heritage Places through the Narrative of Ethnic Identity at the. The Journal of Social Sciences Research, 2:791-799.

Sztompka, P. (2011). Sosiologi Perubahan Sosial. Jakarta: Perdana Media Grup.

Teo, C. B., Khan, N. R., \& Rahim, F. H. (2014). Understanding Cultural Heritage Visitor Behavior: The Case of Malacca as World Heritage City . Procedia - Social and Behavioral Sciences , 130: 1-10.

Urry, J. (2002). Tourist Gaze. London: Sage Publication.

Valentina, V., Marius-Răzvan, S., Login, I. A., \& Anca, C. (2015). Changes in cultural heritage consumption model: Challenges and Limits. Procedia-Social and Behavioral Sciences, 188: 42-52

Widyaningsih, R., \& Purwasito, A. (2018). Misi Suci Grebeg Sudiro. KOMMAS.

Worden, N. (2003). National Identity and Heritage Tourism in Malacca. Indonesia and the Malay World, 31(89): 3143, DOI: $10.1080 / 13639810304447$ 